CZASOPISMO INŻYNIERII LĄDOWEJ, ŚRODOWISKA I ARCHITEKTURY JOURNAL OF CIVIL ENGINEERING, ENVIRONMENT AND ARCHITECTURE

JCEEA, t. XXXIII, z. 63 (2/II/16), kwiecień-czerwiec 2016, s. 187-196

\author{
Tomasz KAŹMIERSKI ${ }^{1}$ \\ Karolina MAZURKIEWICZ ${ }^{2}$ \\ Tomasz SCHILLER ${ }^{3}$
}

\title{
ZASTOSOWANIE METODY AHP W RACJONALNYM PROJEKTOWANIU SIECI WODOCIĄGOWEJ
}

\begin{abstract}
W pracy pokazano przykład zastosowania metody analizy wielokryterialnej do projektowania systemu dystrybucji wody. Porównywano układy sieci zdecentralizowane i scentralizowane, które mają dostarczać wodę w odpowiedniej ilości i jakości do odbiorców zamieszkujących gminę zlokalizowaną w Wielkopolsce o łącznej liczbie mieszkańców ok. 10 000. Modele układów sieci wodociągowych zostały przygotowane w programie Epanet, który umożliwił sprawdzenie parametrów działania, między innymi wysokości ciśnień w węzłach oraz kosztów energii wynikających z tłoczenia wody od źródła do odbiorcy. Skorzystano również z Katalogów Nakładów Rzeczowych, które umożliwiły obliczenie koniecznych nakładów pracy w celu wybudowania każdego z analizowanych rozwiązań sieci. Na potrzeby artykułu przyjęto następujące etapy prac potrzebne do wykonania każdej z inwestycji: wytyczenie trasy rurociągu, usunięcie warstwy ziemi urodzajnej, wykonanie wykopu, umocnienie ścian wykopu, przygotowanie dna, posadowienie rurociągu, zasypanie rurociągu, plantowanie powierzchni. Pozwoliło to na oszacowanie kosztów środowiskowych, inwestycyjnych oraz czasu wykonania każdego z wariantów. Poszczególne warianty układu sieci wodociągowej oceniano przy pomocy kryteriów: niezawodności, jakości wody, kosztów energii, obsługi napraw i remontów, inwestycji, czasu wykonania inwestycji oraz wpływu na środowisko. Przewaga danego wariantu nad innymi zależy w dużej mierze od zastosowanych w projektowaniu rozwiązań oraz koniecznego nakładu prac do ich wykonania. Do oceny wpływu poszczególnych kryteriów na projektowanie sieci wodociągowej zastosowano metodę analizy wielokryterialnej. Wybrano metodę Analytic Hierarchy Process (AHP), która pozwala na ocenę jakościową oraz ilościową wskazanych wariantów. W rezultacie otrzymano ich ranking, który wykazał że przy przyjętych wartościach porównań parami najważniejsza jest jakość wody, wpływ na środowisko ocenianego wariantu oraz niezawodność.
\end{abstract}

\footnotetext{
${ }^{1}$ Tomasz Kaźmierski, Politechnika Poznańska, Pl. M. Skłodowskiej-Curie 5, 60-965 Poznań, tomasz.kazmierski@put.poznan.pl

2 Autor do korespondencji / corresponding author: Karolina Mazurkiewicz, Politechnika Poznańska, Pl. M. Skłodowskiej-Curie 5, 60-965 Poznań, karolina.mazurkiewicz@put.poznan.pl

3 Tomasz Schiller, Politechnika Poznańska, Pl. M. Skłodowskiej-Curie 5, 60-965 Poznań, tomasz.schiller@put.poznan.pl
} 
Słowa kluczowe: analiza wielokryterialna, katalog nakładów rzeczowych, układ scentralizowany, układ zdecentralizowany

\section{Wprowadzenie}

Sieć wodociągowa powinna dostarczyć odbiorcom wodę w odpowiedniej ilości pod odpowiednim ciśnieniem oraz o jakości zgodnej z normami [2, 3, 5]. $\mathrm{Z}$ założeń tych wynika konieczność zapewnienia układu sieci, który spełni te wymagania. Skutkiem ich przyjęcia i przyznania, że są one ważne dla przyszłych odbiorców wody jest między innymi konieczność obliczenia kosztów inwestycyjnych, eksploatacyjnych, czasu wykonania inwestycji, niezawodności projektowanej sieci, oszacowania oddziaływania inwestycji na środowisko. Następnie należy porównać różne warianty sieci spełniające założenia. Taki sposób postępowania pozwoli na zidentyfikowanie rozwiązania racjonalnego. Porównania wariantów sieci z uwzględnieniem przyjętych przez projektanta kryteriów można dokonać za pomocą metod wielokryterialnego wspomagania decyzji.

Celem artykułu jest zaproponowanie zestawu kryteriów oraz pokazanie rankingu wariantów, który pozwoli na oszacowanie ich wpływu na projektowanie sieci wodociągowej.

W artykule przyjęto metodę AHP (Analytic Hierarchy Process), która pozwala na uwzględnienie kryteriów ilościowych oraz jakościowych. Jest to istotne ponieważ niektóre z kryteriów trudno jest ocenić ilościowo (np. wpływ na środowisko).

Na potrzeby artykułu przygotowano w programie Epanet kilka wariantów modeli sieci wodociągowej zasilającej gminę zlokalizowaną w Wielkopolsce o łącznej liczbie mieszkańców ok. 10 000. Różnią się one średnicami przewodów, typem oraz ilością pomp oraz lokalizacją SUW wraz z pompownią. Układy scentralizowane oznaczano literą "s" w nazwie, a zdecentralizowane literą "z". Każdy z wariantów spełnienia wymagania przeciwpożarowe.

\section{Kryteria oceny wariantów}

W pracy uwzględniono następujące kryteria oceny:

- niezawodność,

- jakość wody,

- koszt energii,

- koszt obsługi, napraw i remontów,

- koszt inwestycji,

- czas wykonania inwestycji,

- wpływ na środowisko.

Niezawodność jest to właściwość polegająca na zdolności systemu do realizacji swoich funkcji $\mathrm{w}$ określonych warunkach istnienia i eksploatacji oraz w założonym czasie. Na niezawodność działania mają więc wpływ różne czyn- 
niki. W artykule niezawodność została zbadana poprzez zmienność ciśnienia, która może spowodować nieszczelności oraz doprowadzić do przerwania dopływu wody do rejonu miasta, który przez dany rurociąg jest zasilany. Należy więc minimalizować zmiany ciśnienia przy jednoczesnym zapewnieniu jego odpowiedniej wartości w punktach czerpalnych.

Jakość wody to kryterium, które musi być zachowane w celu zapewnienia mieszkańcom wody o odpowiednim składzie fizyko-chemicznym. W przypadku rozważań wykonanych w artykule oparto się na wieku wody, który obrazuje jak długi czas woda przybywała w układzie zanim trafiła do odbiorcy. Należy maksymalizować jakość wody obniżając jej wiek.

Koszty energetyczne związane są z ceną transportu $1 \mathrm{~m}^{3}$ wody. Jest to wartość, którą należy minimalizować.

Koszt obsługi, napraw i remontów związany jest z wielkością systemu oraz ilością SUW. Przeprowadzone symulacje różnych wariantów sieci wykazały, że w celu zapewnienia odpowiedniej pracy układu różnice w długości sieci są zazwyczaj nieznaczne (w badanym regionie wynosiły maksymalnie 16\%) i dlatego skupiono się głównie na ilości SUW. Im większa ich ilość tym więcej pracowników należy zatrudnić i tym większe prawdopodobieństwo awarii pomp (ze względu na ich większą ilość). Należy więc dążyć do jak najmniejszej ilości SUW.

Koszt inwestycyjny związany jest z długością sieci, zastosowanymi średnicami oraz ilością budowanych SUW. W artykule cała sieć w każdym z wariantów wykonana jest $\mathrm{z}$ rur $\mathrm{z}$ tego samego materiału o tym samym prognozowanym okresie eksploatacji. Koszt inwestycyjny należy minimalizować.

Czas wykonania inwestycji związany jest $\mathrm{z}$ zastosowanymi $\mathrm{w}$ wariantach rozwiązaniami oraz z zastosowanymi metodami pracy. Jest to kryterium, które związane jest z możliwościami wykonawcy. Powinniśmy dążyć do jego minimalizacji uwzględniając jednak wielkość frontu robót.

Otaczające nas środowisko jest jednym z najbardziej istotnych kryteriów wykonywanych inwestycji. Należy ograniczyć stopień ingerencji w otoczenie minimalizując wykopy, ograniczając ilość spalin doprowadzanych do otoczenia czy też ilość energii koniecznej do transportu wody. Należy minimalizować wpływ na środowisko.

\section{Metoda AHP}

W celu wyboru racjonalnego wariantu sieci wodociągowej skorzystano z metody AHP. Jest to jedna z metod wielokryterialnych, w której należy określić kryteria oceny oraz wzajemne relacje poszczególnych wariantów względem nich. Wzajemne relacje pomiędzy kryteriami określono za pomocą skali porównań parami, która pozwala równocześnie ocenić cechy ilościowo oraz jakościowo: 
1 - Jednakowa istotność. Oba czynniki w jednakowym stopniu przyczyniają się do osiągnięcia celu.

3 - Niewielka przewaga. Osąd i doświadczenie nieznacznie przedkładają jeden czynnik nad drugi.

5 - Silna przewaga. Osąd i doświadczenie silnie przedkładają jeden czynnik nad drugi.

7 - Bardzo silna przewaga. Jeden czynnik jest bardzo silnie przedkładany nad drugi i praktyka potwierdza tą przewagę.

9 - Absolutna przewaga. Przewaga jednego czynnika nad drugim jest absolutna i potwierdzona w najwyższym stopniu.

Wartości pośrednie 2, 4, 6, 8 stosuje się w razie konieczności, gdy wybór kolejnych liczb nieparzystych nie oddaje relacji między wariantami lub kryteriami. W przypadku ocen o relacji odwrotnej stosuje się odwrotność podanych liczb np. 1/7 (bardzo silna przewaga drugiego z porównywanych wariantów). Wynik porównań zamieszczono w tabeli 1.

\section{Obliczenia nakładu prac}

Wymagany zakres robót ziemnych wpływa na część kryteriów, tj. na koszt inwestycji, czas jej wykonania oraz oddziaływanie na środowisko. Przygotowując modele sieci założono, że przewody wodociągowe wykonane zostaną z polietylenu. $\mathrm{W}$ obliczeniach przyjęto więc ich wymagane minimalne przykrycie równe 1,7 m. Przyjęta wartość wynika z zachowania odpowiedniego zagłębienia przyłączy wodociągowych podczas stosowania trójników siodłowych zgrzewanych elektrooporowo [1]. Na podstawie wymagań technicznych COBRTI INSTAL [4] przyjęto minimalną szerokość dna wykopu - przyjęto wykop wąskoprzestrzenny (o szerokości dna do 1,5 m), oszalowany. Obliczono wysokość oraz szerokość wykopów w zależności od średnicy rury, a w kolejnym etapie objętość oraz powierzchnię wykopu i jego skarp. Następnie zastosowano Katalogi nakładów rzeczowych (KNR) do wyliczenia koniecznych nakładów pracy w celu wybudowania rurociągów, według niżej wymienionych etapów:

- wytyczenie trasy rurociągu,

- usunięcie warstwy ziemi urodzajnej,

- wykonanie wykopu,

- umocnienie ścian wykopu,

- przygotowanie dna,

- posadowienie rurociągu,

- zasypanie rurociągu,

- plantowanie powierzchni. 
Tab. 1. Porównanie kryteriów zgodnie ze skalą porównań parami

Table 1. Comparison of criteria in accordance with the scale pairwise comparisons

\begin{tabular}{|c|c|c|c|}
\hline Lp. & Kryterium 1 & Kryterium 2 & $\begin{array}{c}\text { Porównanie } \\
\text { kryterium } \\
\text { pierwszego } \\
\text { z drugim }\end{array}$ \\
\hline 1. & Niezawodność & Jakość wody & $1 / 2$ \\
\hline 2. & Niezawodność & Koszt energii & $2 / 1$ \\
\hline 3. & Niezawodność & $\begin{array}{l}\text { Koszt obsługi, napraw } \\
\text { i remontów }\end{array}$ & $2 / 1$ \\
\hline 4. & Niezawodność & Koszt inwestycji & $2 / 1$ \\
\hline 5. & Niezawodność & Czas wykonania inwestycji & $2 / 1$ \\
\hline 6. & Niezawodność & Wpływ na środowisko & $2 / 1$ \\
\hline 7. & Jakość wody & Koszt energii & $2 / 1$ \\
\hline 8. & Jakość wody & $\begin{array}{l}\text { Koszt obsługi, napraw } \\
\text { i remontów }\end{array}$ & $4 / 1$ \\
\hline 9. & Jakość wody & Koszt inwestycji & $2 / 1$ \\
\hline 10. & Jakość wody & Czas wykonania inwestycji & $5 / 1$ \\
\hline 11. & Jakość wody & Wpływ na środowisko & $1 / 1$ \\
\hline 12. & Koszt energii & $\begin{array}{l}\text { Koszt obsługi, napraw } \\
\text { i remontów }\end{array}$ & $2 / 1$ \\
\hline 13. & Koszt energii & Koszt inwestycji & $1 / 3$ \\
\hline 14. & Koszt energii & Czas wykonania inwestycji & $3 / 1$ \\
\hline 15. & Koszt energii & Wpływ na środowisko & $1 / 2$ \\
\hline 16. & $\begin{array}{l}\text { Koszt obsługi, napraw } \\
\text { i remontów }\end{array}$ & Koszt inwestycji & $1 / 3$ \\
\hline 17. & $\begin{array}{l}\text { Koszt obsługi, napraw } \\
\text { i remontów }\end{array}$ & Czas wykonania inwestycji & $3 / 1$ \\
\hline 18. & $\begin{array}{l}\text { Koszt obsługi, napraw } \\
\text { i remontów }\end{array}$ & Wpływ na środowisko & $1 / 3$ \\
\hline 19. & Koszt inwestycji & Czas wykonania inwestycji & $3 / 1$ \\
\hline 20. & Koszt inwestycji & Wpływ na środowisko & $2 / 1$ \\
\hline 21. & $\begin{array}{l}\text { Czas wykonania } \\
\text { inwestycji }\end{array}$ & Wpływ na środowisko & $1 / 5$ \\
\hline
\end{tabular}


Każdy z wariantów scentralizowanych wymaga zaprojektowania sieci o większej długości całkowitej niż w wariantach zdecentralizowanych (rys. 1). Związane jest to z połączeniem w jeden układ miejscowości często oddalonych od siebie o kilka kilometrów. W przypadku ustalonych na potrzeby tej pracy wariantów układy scentralizowane mają o około $16 \%$ dłuższą sieć od wariantów zdecentralizowanych, taka jest też różnica nakładu pracy dotycząca wariantów. W każdym z wariantów około $70 \%$ zastosowanych rur ma średnicę $96,8 \mathrm{~mm}$ oraz 110,2 mm. W przypadku wariantu S2 i S4 zastosowano tylko średnicę 96,8 $\mathrm{mm}$ i to te rury stanowią około $70 \%$ wszystkich zastosowanych średnic. W wariantach S1 i S3 największą zastosowaną średnicą jest 312,8, która występuje tylko przy SUW. W wariancie S3 rolę głównej magistrali pełni średnica 277,6, dla S1 jest to 220,4, a dla innych wariantów 198,2. Zmniejszanie zastosowanych średnic ma na celu zwiększenie prędkości przepływu i tym samym zmniejszenie czasu przebywania wody w układzie. Niestety ze względu na symulowanie w modelach pożaru średnica 96,8 okazała się najniższą możliwą do zastosowania. Powoduje to występowanie w układzie niskich prędkości przepływu, szczególnie na końcówkach sieci. Zastosowanie metody AHP pozwoliło jednak na uwzględnienie zmian prędkości w poszczególnych wariantach przy zastosowaniu skali porównań parami.

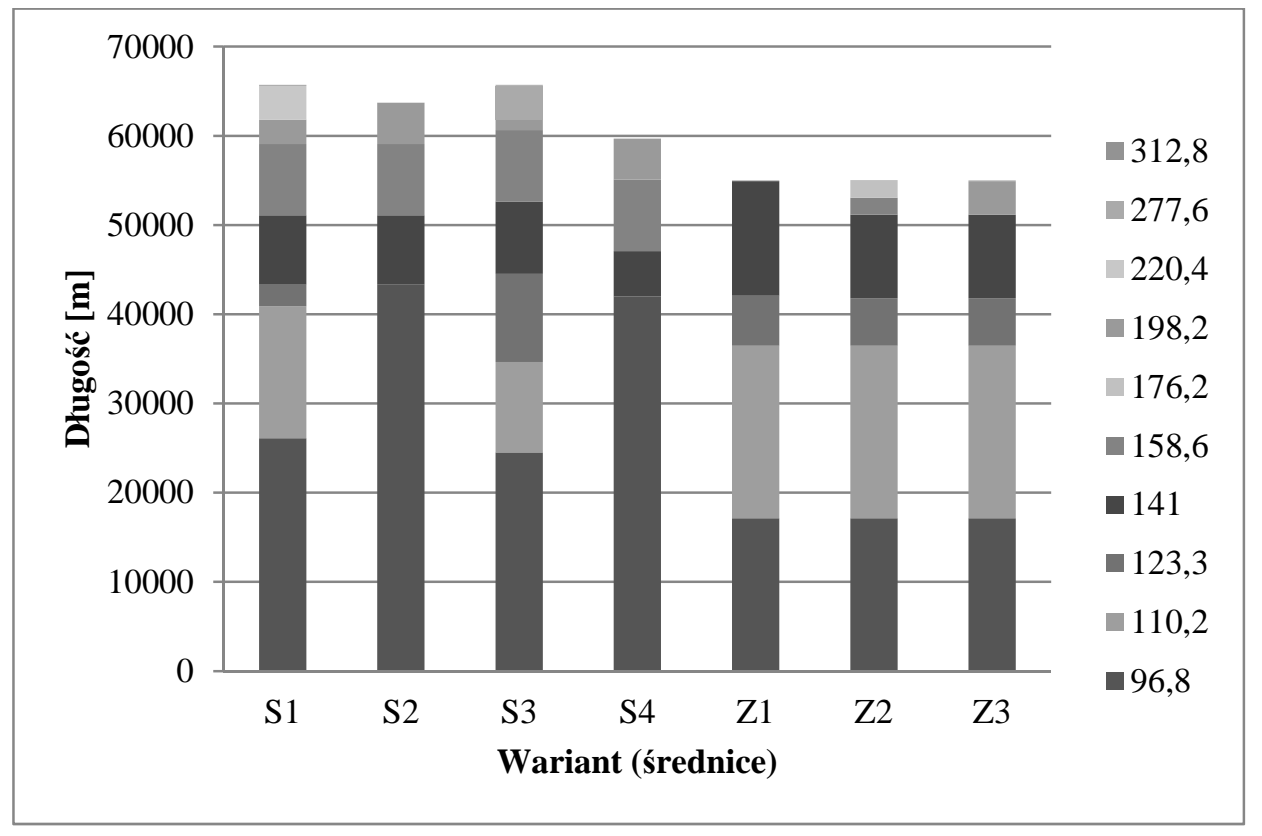

Rys. 1. Długości przewodów wykorzystanych w poszczególnych wariantach

Fig. 1. Length of pipes used in different variants 
Rysunek 2 przedstawia czas konieczny do wykonania poszczególnych etapów prac według wariantów w przypadku zastosowania maszyn. Jak można odczytać z wykresu całkowity czas potrzebny na wykonanie wariantów zawiera się w przedziale od około 170 tysięcy do około 200 tysięcy godzin. Przyjmując $8 \mathrm{~h}$ czas pracy wynosi to od około 70 tysięcy do 90 tysięcy dniówek. Przy pracy ekipy składającej się ze 100 ludzi czas wykonania poszczególnych wariantów to od około 7 do 9 miesięcy. Należy jednak pamiętać, że nie uwzględniono tu harmonogramu robót, który może skrócić ten czas. Przyjęto koszt zatrudnienia 1 pracownika równy $4000 \mathrm{zł} \mathrm{miesięcznie.} \mathrm{Całkowity} \mathrm{koszt} \mathrm{pracy} \mathrm{wynosi} \mathrm{więc} \mathrm{od}$ około 4,4 do 5,2 milionów złotych. Koszt pracy maszyn uśredniono przyjmując, że 1 miesiąc pracy wraz z operatorem to koszt 14000 złotych. Praca maszyn kosztuje więc od około 364 do około 448 tysięcy złotych. Około 66\% czasu wykorzystane zostaje na umocnienie ścian wykopu, a po około $10 \%$ na wykonanie podłoża oraz ułożenie rurociągu. Te trzy etapy wykonane są tylko z pomocą pracy ludzi stąd ich czas trwania dominuje nad innymi etapami.

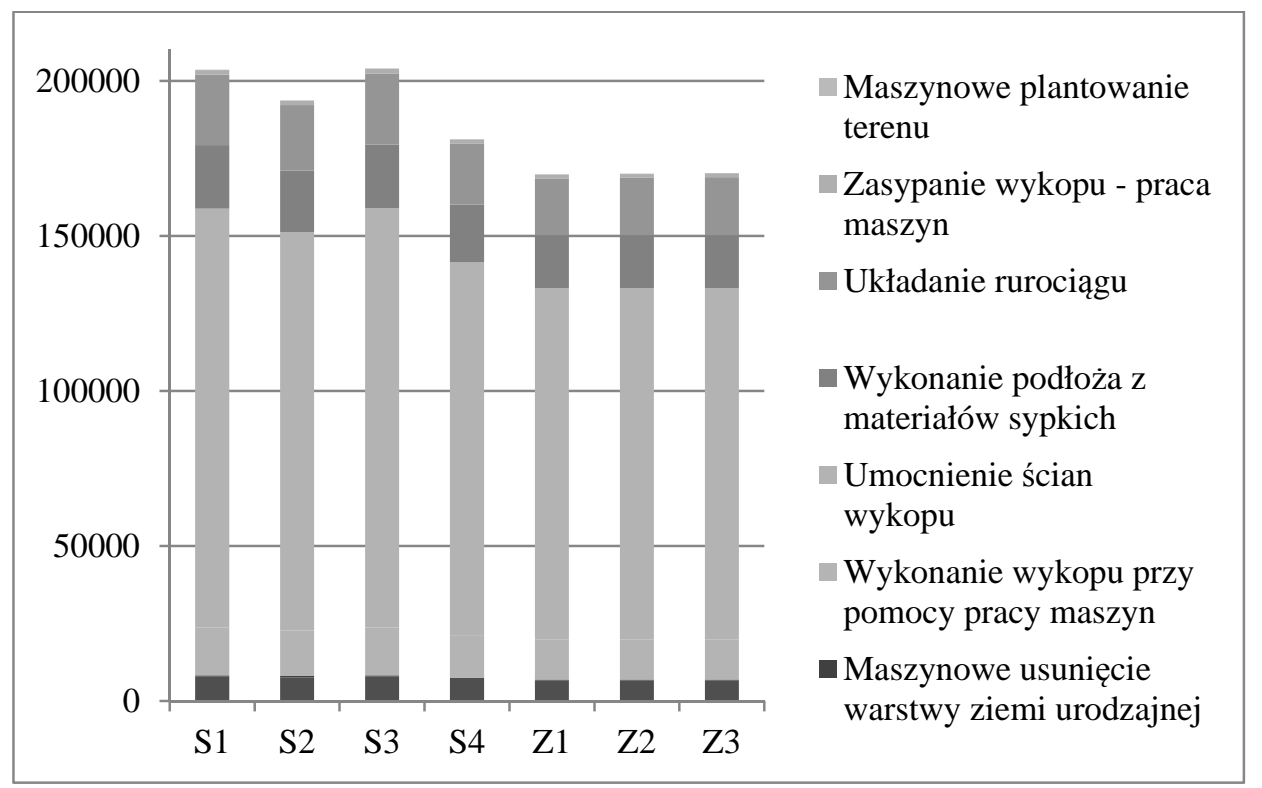

Rys. 2. Czas konieczny do wykonania poszczególnych etapów prac według wariantów w przypadku zastosowania maszyn

Fig. 2. The time required for the various stages of variants-rods in the case of the use of machines 


\section{Porównanie wariantów z zastosowaniem metody AHP - wnioski}

Warianty zostały porównane względem kryteriów zgodnie ze skalą porównań parami zamieszczoną $\mathrm{w}$ punkcie trzecim artykułu. W wyniku otrzymano ranking wariantów zamieszczony na rysunku 3.

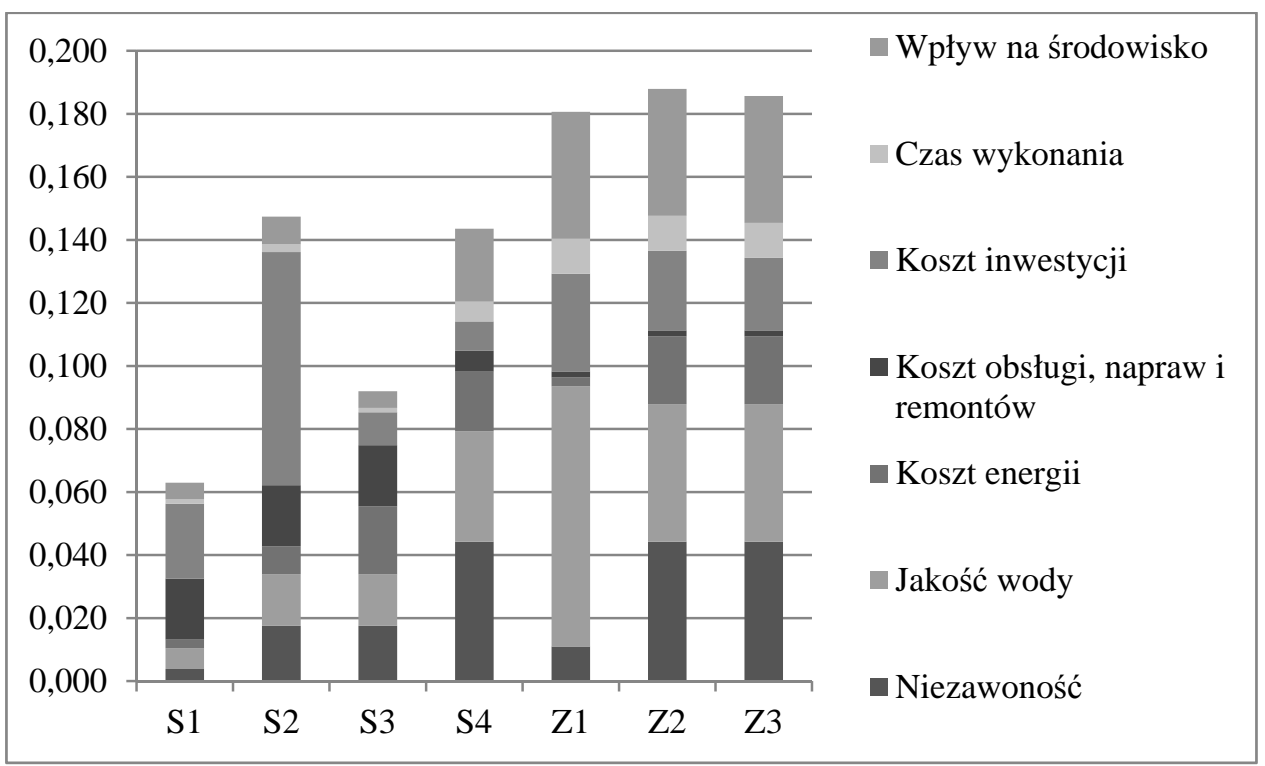

Rys. 3. Ranking wariantów

Fig. 3. Ranking alternatives

Po wykonaniu porównań parami okazało się, że najważniejsze jest kryterium jakości wody, kolejnymi zaś koszt inwestycyjny i niezawodność. Po wykonaniu rankingu wariantów stwierdzono, że na ocenę końcową wariantów zdecentralizowanych wpłynęły głównie niezawodność (około 6-24\%), jakość wody (około 23-46\%) oraz wpływ na środowisko (około 22\%). Można więc stwierdzić, że pomimo iż koszt inwestycyjny jest kryterium istotnym dla inwestorów to po wzięciu pod uwagę relacji pomiędzy wariantami okazuje się parametrem mniej ważnym. Jedynie w przypadku wariantu S2 stanowił aż $50 \%$ oceny końcowej oraz w wariancie S1 około $38 \%$. W innych wariantach wynosił od około 6 do około $17 \%$. Zgodnie z wykresem 3 po uwzględnieniu wszystkich kryteriów najbardziej racjonalnym wariantem jest wariant zdecentralizowany Z2. Ma on w porównaniu z innymi wariantami dobry koszt inwestycyjny, wpływ na środowisko, jakość wody oraz niezawodność działania. Czas wykonania również jest krótszy niż dla innych wariantów. Jedynie koszt obsługi, napraw i remontów jest wyższy co jest związane $\mathrm{z}$ większą liczbą stacji uzdatniania wody i konieczno- 
ścią zatrudnienia większej liczby pracowników. Można również stwierdzić, że wszystkie warianty zdecentralizowane mają lepszy ranking od wariantów scentralizowanych. Związane to jest głownie $\mathrm{z}$ ich mniejszym wpływem na środowisko oraz lepszą jakością wody, które to kryteria miały jedną z wyższych wartości oceniania poszczególnych wariantów.

\section{Literatura}

[1] Aquanet S.A.: Projektowanie, wykonawstwo sieci wodociągowych i kanalizacyjnych oraz przyłączy. Wymagania ogólne, Poznań 2013.

[2] Elton A., Brammer L.F.,Tansley N.S.: Water quality modeling in distribution networks, Journal AWWA, Vol. 87, No. 7, 1995, pp. 44-52.

[3] Reddy L.S., Ormsbee L.E.; Wood D.J.: Time-Averaging Water Quality Assessment, Journal AWWA, Vol. 87, No. 7, 1995, pp.64-73.

[4] Wymagania techniczne wykonania i odbioru sieci kanalizacyjnych zalecane do stosowania przez Ministerstwo Infrastruktury, Wymaganie techniczne COBRTI Instal, Zeszyt 9, Warszawa 2003.

[5] Bromberek Z., Kaźmierski T., Mazurkiewicz K., Schiller T., Mróz T.M.: Metoda planowania zabudowy zrównoważonej w oparciu o racjonalną infrastrukturę wodno-ściekową [w:] INFRAEKO 2014: Nowoczesne miasta. Infrastruktura i środowisko, IV Międzynarodowa Konferencja Naukowo-Techniczna, pod red. J. Dziopaka, D. Słysia, A. Stec, [organiz.] Katedra Infrastruktury i Ekorozwoju Politechniki Rzeszowskiej, Politechnika Rzeszowska, Rzeszów 2014, s. 19-32, ISBN 978-83-7199-937-2.

\section{THE USAGE OF AHP METHOD IN RATIONAL DESIGNING OF WATER SUPPLY SYSTEM}

\section{S u m m a r y}

The article presents an example of the use of multi-criteria analysis method in designing of a water supply system. Centralized and decentralized network systems have been compared, which aim to supply a community of appx. 10000 people in Wielkopolska with water of an appropriate quality and in a proper quantity. The models of water network system have been prepared in the Epanet program, which enabled to check work parameters, among others pressure in nodes and energy cost resulting from water pumping from source to consumer. By using the Catalogues of In-kind Expenditures, the work input necessary to build each of analyzed network solutions has been calculated. In the article, the following work steps needed to execute each investment have been assumed: defining the route of the pipeline, removal of the fertile soil layer, trench excavation, reinforcement of the walls of the excavation, preparation of the bottom of the excavation, foundation of the pipeline, backfilling over the pipeline and restoring the original ground surface profile. This enabled to estimate environmental and investment cost as well as the execution time of each option. The individual options of water network systems have been assessed against the following criteria: reliability, water quality, energy cost, maintenance cost, investment cost, investment execution time and environmental impact. The superiority of one option over other depends, to a great extent, on solutions used in designing and work input necessary for their implementation. In order to assess the impact of different options on designing of water network, the multi-criteria analysis method has been used. The chosen method of Analytic Hierarchy Process 
(AHP) allows to judge the options from both a qualitative and quantitative perspective. As a result a ranking has been prepared, which proves that for adopted values of comparison in pairs the most important are: water quality, environmental impact of assessed option and its reliability.

Keywords: multi-criteria analysis, catalogue of in-kind expenditures, centralized water supply system, decentralized water supply system

DOI:10.7862/rb.2016.159

Przestano do redakcji: 01.05.2016 r.

Przyjęto do druku: 28.06.2016 r. 